\title{
sciendo
}

10.2478/msd-2019-0004

\section{STUDY ON MILK AND DAIRY PRODUCTS CONSUMERS BEHAVIOR AND PREFERENCES IN SIBIU COUNTRY FROM ROMANIA}

\author{
Maria Adelina, CONSTANTINESCU ${ }^{1}$, Mihaela Adriana, TIŢA $^{2}$, Ovidiu, TIŢA ${ }^{3}$, Cristina, BĂTUŞARU ${ }^{4}$ and \\ Cristina POPOVICI ${ }^{5}$ \\ 1’Lucian Blaga" University of Sibiu, Romania, constantinescumariaadelina@yahoo.com \\ 2"'Lucian Blaga" University of Sibiu, Romania, mihaela.tita@ulbsibiu.ro \\ "'Lucian Blaga" University of Sibiu, Romania, ovidiu.tita@ulbsibiu.ro \\ ${ }^{4}$ Academy of Land Forces "Nicolae Bălcescu" of Sibiu, Romania, cristina.batusaru@yahoo.com \\ 5"Technical University" of Moldova, cristina.popovici@,toap.utm.md
}

\begin{abstract}
Milk and dairy products are some of the most popular and consumed food products. They can be eaten from an early age and bring a significant nutritional contribution to the health of the consumer. The main objective of this study was to identify socio-economic and demographic factors that influence consumer preferences for dairy products. The study was conducted using a questionnaire and targeted two types of dairy products: packaged dairy products and unpackaged dairy products.
\end{abstract}

KEY WORDS: dairy products, consumer, questionnaire, behavior, preference

\section{INTRODUCTION}

Milk is a white-yellowish liquid with a sweet taste and characteristic smell and with a complex chemical composition [1]. Cow's milk is most commonly used in human food, because it is most similar to breast milk [2]. Milk and dairy products are an important source of nutrients such as protein, calcium, phosphorus, vitamin B2 and vitamin B12 [3].

The dairy products sector is extremely vibrant and it's experiencing a real increase in popularity. Numerous studies conducted by FAO, WHO and IDF show that global dairy products consumption and production have a significant increase. According to the OECD and FAO forecasts, we will see a significant increase in dairy consumption in North African countries in the Middle East and possibly an exceptional increase in Asian countries. Over the past five decades, annual milk and dairy products consumption (excluding butter) has declined considerably in North America and Oceania. While milk and butter consumption has decreased, the cheese consumption is high. The European Union is still the world's largest consumer of milk and dairy products. The EU is now the largest cheese consumer with $45.5 \%$ of global consumption. The other major consumer of cheese is North America (36\%), South America accounts for $8 \%$ of this world market, and the former Soviet Union, $6.5 \%$ [4]

The main objective of this study is to examine the decisional psychological factors correlated with the personal factors in the process of purchasing dairy products in Sibiu country of Romania. This study is based on socio-economic and demographic factors that influence consumer preferences for dairy products. To realize this market survey was used a questionnaire. A questionnaire is a research tool that consists of a series of questions in order to gather certain information from people. The questionnaire was invented by Sir Francis Galton and was designed for statistical analysis of responses.
As a research tool, the questionnaire has a number of advantages: it is cheap, it does not require much effort on the part of the interviewer and often has standardized answers that make it easy to fill in [5].

\section{METHODS}

The data contained in this research was obtained from a study both online and face to face and which consisted in completing a questionnaire by consumers of dairy products in Sibiu country. This study was attended by 250 people residing in Sibiu county between 18-25 years, 26-40 years, 41-55 years, over 55 years old and with different levels of studies: vocational school, high school, university studies, postgraduate studies. This questionnaire included questions about the reasons for purchasing dairy products, purchasing frequency, how often dairy products are consumed, dairy preference: packaged or unpackaged and the place of purchasing.

\section{RESULTS AND DISCUSSION}

In order to realize the market survey, we decided to use a questioner because is the simplest and the best know method of analysing the desire to buy and trends in the milk and dairy products consumption. The questionnaire used contained ten questions and the results obtained for each individual question are as follows:

a. Do you consume milk and dairy products?

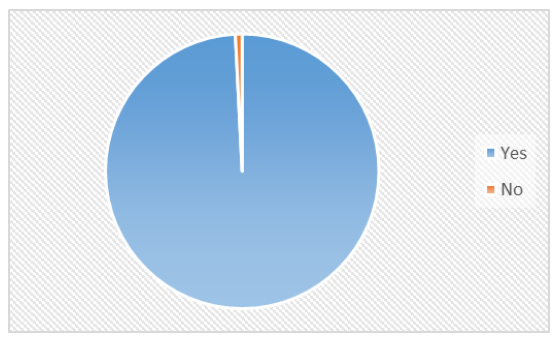

Figure 1. Evaluation of the results of question number 1 
As can be seen in the above-mentioned garment, most interviewees have said they are milk and dairy products consumers and two people interviewed said they did not consume any dairy products.

b. What milk choices do you prefer?

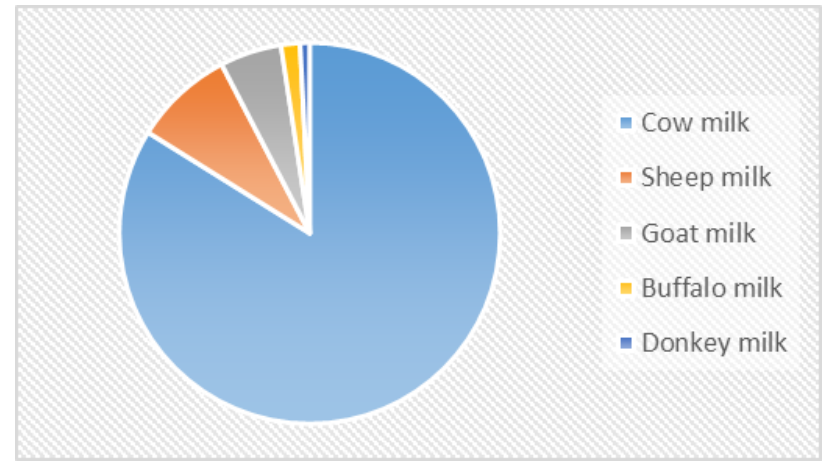

Figure 2. Evaluation of the results of question number 2

According to the chart above, most people said they are cow milk consumers, more exactly 208 people. They are followed by those who prefer sheep's milk, goat's milk and the least ones who consume buffalo and donkey milk. A quite important reason for which most respondents prefer cow's milk is that it is similar with breast milk.

c. What is the range of dairy products most commonly consumed by you?

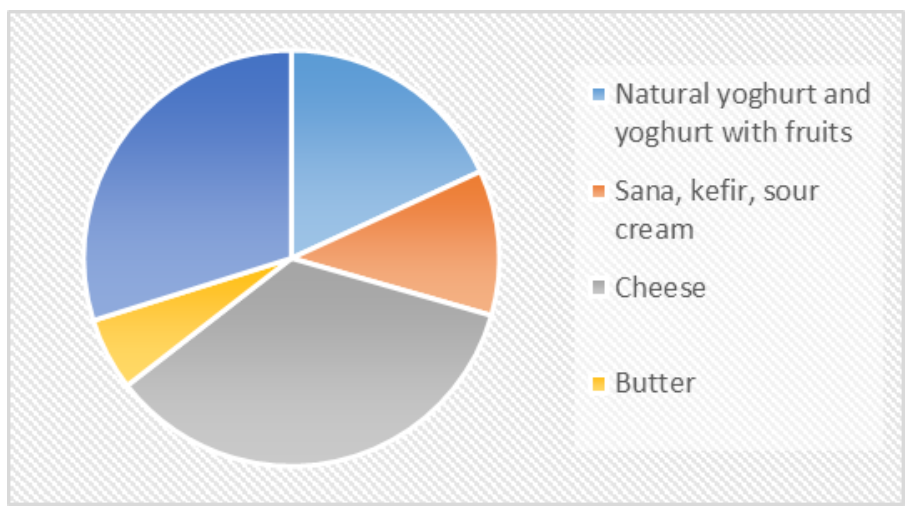

Figure 3. Evaluation of the results of question number 3

Most people said that they prefer to consume cheese, more exactly 96 people, followed by those who most often consume simple or flavored milk. People who said that prefer natural yoghurt and yoghurt with fruits were 45 , followed by those who consume sana, kefir, sour cream and fewer prefer butter.

d. How often do you buy milk or dairy products?

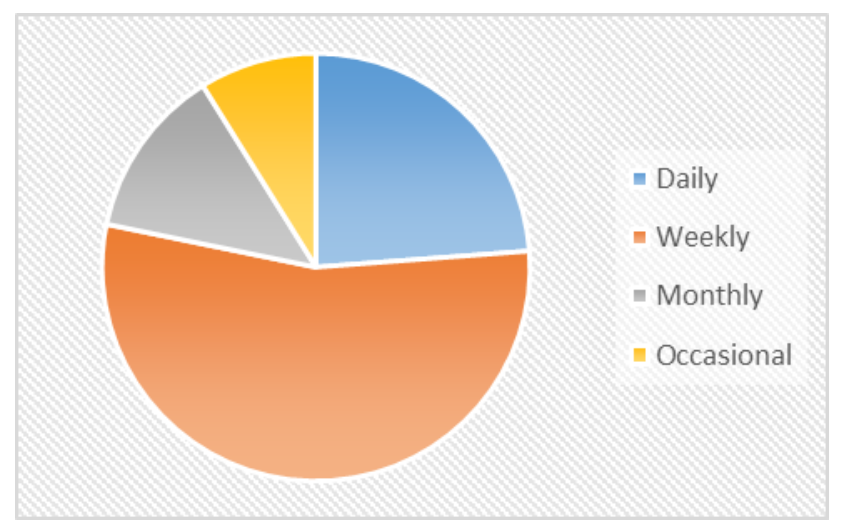

Figure 4. Evaluation of the results of question number 4
According to the chart above, most people prefer to buy weekly dairy products. They are followed by those who buy daily dairy products, then those who buy monthly and the few who purchase dairy products occasionally.

e. What is the main reason for purchasing dairy products?

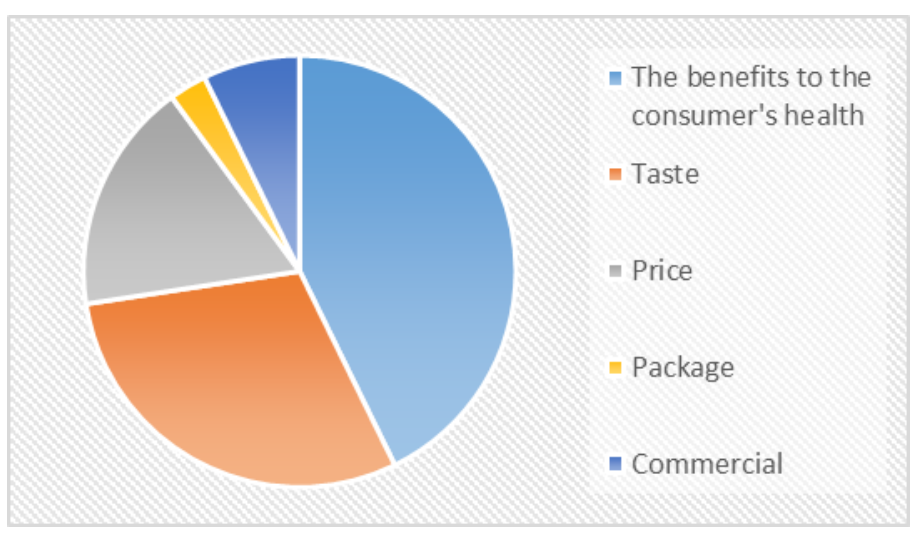

Figure 5. Evaluation of the results of question number 5

The most important reason for purchasing milk and dairy products is the benefit to the consumer's health. Most people chose this option. These are followed by those who appreciate their taste very much. Fewer people chose packaging and advertising as their primary reason.

f. What method of packaging do you prefer for dairy products?

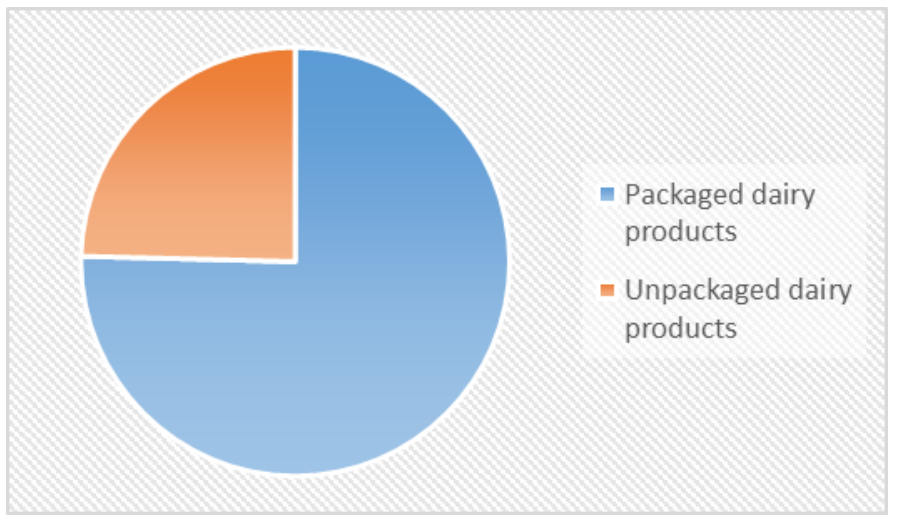

Figure 6. Evaluation of the results of question number 6

Most interviewees prefer packaged dairy products and 61 of the respondents prefer to buy dairy products unpackaged.

g. Where do you prefer to buy dairy products?

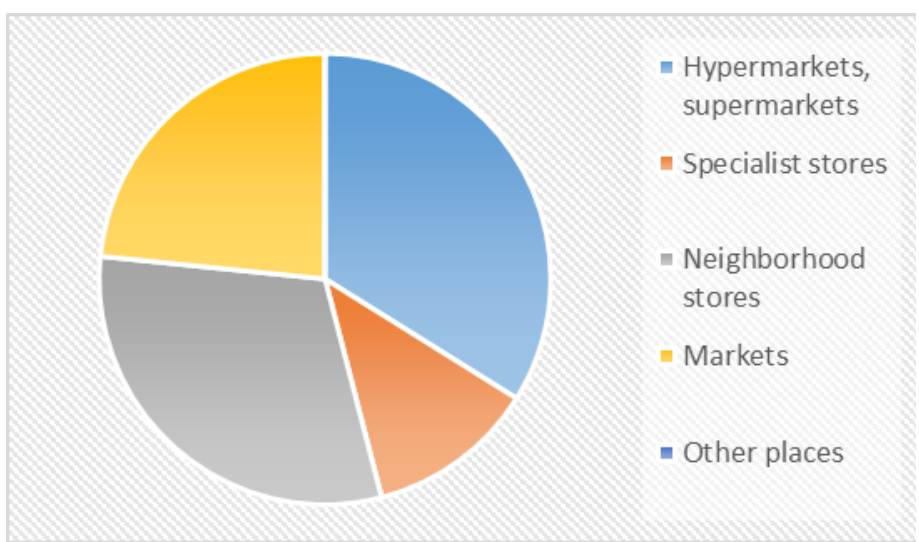

Figure 7. Evaluation of the results of question number 7

Most people prefer to buy dairy products from hypermarkets or supermarkets, followed by those who prefer to buy these products from specialist stores and markets. The few people22 
choose to buy milk or dairy products from neighborhood stores.

h. What is the last graduated school?

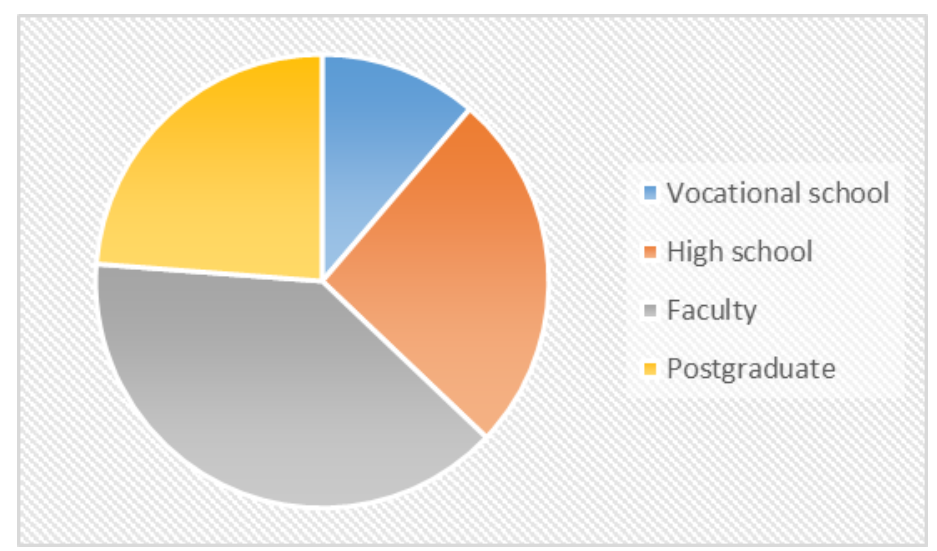

Figure 8. Evaluation of the results of question number 8

According to the chart above, most people who answered the questionnaire are faculty graduates, followed by those with only high school studies. The fewer respondents have completed a vocational school.

i. How old are you?

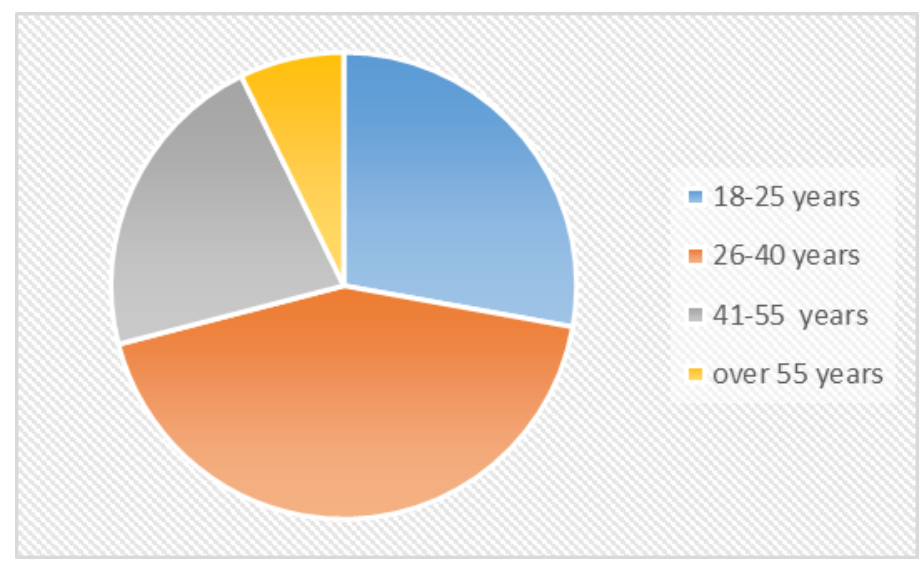

Figure 9. Evaluation of the results of question number 9

Most respondents are between 26 and 40 years, followed by those between 18 and 25 years. The fewer respondents are over 55 years.

j. In what area do you live?

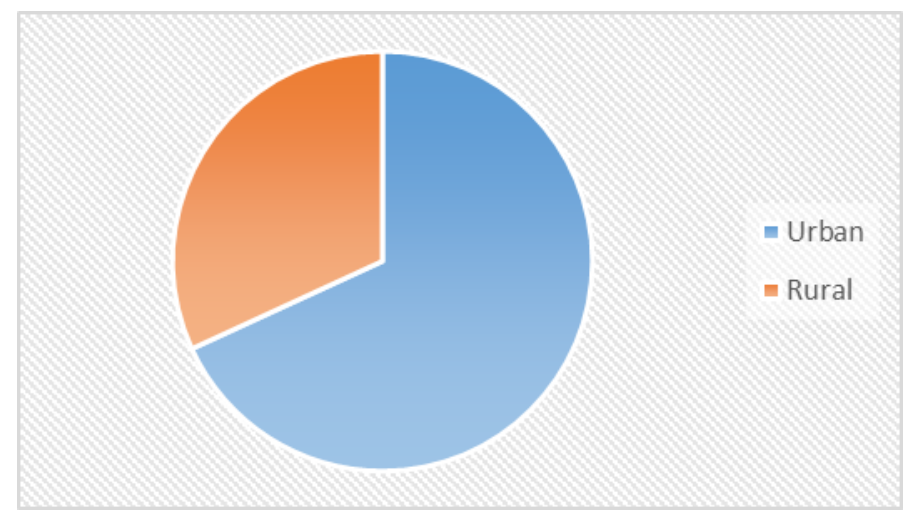

Figure 10. Evaluation of the results of question number 10
According to the chart above, most people who participated in this market survey live in the urban area and 79 of them live in rural areas.

Thus, most dairy consumers prefer cow's milk and the most commonly bought dairy category is cheese. The main reason why they choose to consume milk and dairy products are the benefits to the health of consumers, for this reason the frequency of buying them is weekly. Depending on the level of studies, most people with faculty education buy packaged dairy products from specialized stores or hypermarkets, and those with high school or vocational education prefer unpackaged dairy products from markets or neighborhood stores. People aged under 40 buy these products weekly or even daily, and most people over the age of 40 prefer to purchase this range of food products weekly or even monthly.

\section{CONCLUSIONS}

Milk and dairy products are increasingly appreciated by consumers around the world. This is also visible at Sibiu county level due to the market survey conducted on a sample of 250 people who have a stable residence in this county. The obtained results were influenced by the educational level, but also by the age of the respondents. The main reason for purchasing these foods are the benefits they have, which shows that more and more people are focused on safe foods and on food products that can bring a bigger nutritional contribution. Another very important thing that shows consumers' orientation towards safe products is that more and more people opt for packaged foods, so their microbiological load is much better controlled and food poisoning can be avoided.

Using a questionnaire to realize this market survey was the best choice because it is easy to complete and does not require much time for response to questions. In order to obtain optimal results, in a market survey it is necessary to take account as many consumer-related factors (economics, education, age) [6]. These factors also influenced the results of this market survey, some answers being influenced by the educational level and the age of the respondents.

\section{REFERENCES}

1. Galatanu, Diana, Compoziţia laptelui, Gazeta de Agricultură, (2014)

2. Isaic-Maniu, Alexandru, Chestionarul, Metode de cercetare-Curs stud. AMP master, Academia de Studii Economice, Bucureşti: p. 1-11, (2013)

3. Kurajdová, Klaudia, Táborecká-Petrovipová, Janka and Kašpákováa, Alena, Factors Influencing Milk Consumption and Purchase Behavior - Evidence from Slovakia, Faculty of Economics Matej Bel University,Tajovského Banská Bystrica, Slovakia: p. 573-580, (2015)

4. Merdji, M'hamed, Gacic, Marion Kussmann and Ciheam-Maim, Selma Tozanli, The dairy products market - Documentary study, p. 6 -14, ( 2015)

5. Tiţa, Mihaela, Tehnologii și utilaje în industria laptelui și a produselor din lapte vol 1, Editura Universităţii "Lucian Blaga" din Sibiu, Sibiu, (2001)

6. Voicu, Mirela Cristina, Characteristics of the consumer preferences research process, p. 126-134, (2013) 